\title{
Research on the Effect of External Resource Acquisition on Process Innovation
}

\author{
Mingming Ding*, Xiaoqin Huang \\ School of Business Administration, South China University of Technology, Guangzhou, China \\ Email: *ding2ming@yeah.net
}

How to cite this paper: Ding, M.M. and Huang, X.Q. (2019) Research on the Effect of External Resource Acquisition on Process Innovation. Open Journal of Business and Management, 7, 755-774. https://doi.org/10.4236/ojbm.2019.72050

Received: March 5, 2019

Accepted: April 6, 2019

Published: April 9, 2019

Copyright $\odot 2019$ by author(s) and Scientific Research Publishing Inc. This work is licensed under the Creative Commons Attribution International License (CC BY 4.0).

http://creativecommons.org/licenses/by/4.0/

\section{cc) (7) Open Access}

\begin{abstract}
In the past, research on the effect of external resource integration on technological innovation focused on product innovation, and process innovation was largely ignored due to its silence. The study takes the high-tech manufacturing industry in China's Bohai Rim, Yangtze River Delta and Pearl River Delta regions as a sample, and empirically analyzes the impact of government support, industry-university-research knowledge integration, and customer knowledge integration on corporate process innovation. The study found that: 1) government support can significantly promote process innovation, industry-university-research knowledge integration, and improve corporate performance. 2) The industry-university-research knowledge integration has a relatively significant positive impact on process innovation, but has no significant impact on firm performance. 3) Customer knowledge integration negatively affects process innovation and has no significant impact on firm performance.
\end{abstract}

\section{Keywords}

Process Innovation, Government Support, Industry-University-Research Knowledge Integration, Customer Knowledge Integration

\section{Introduction}

Innovation is critical to the survival and development of a company. Enterprise innovation is usually divided into product innovation and process innovation. In order to obtain and maintain competitive advantage, enterprises often need to have both innovation capabilities [1] [2]. In the existing innovation literature, a large amount of research has focused on product innovation. In contrast, process innovation has been largely ignored [3]; research on process innovation needs to attract enough attention from researchers. Lim et al. (2010) [4] pointed out 
process innovation can also have a positive impact on firm performance, especially for manufacturing companies, where the development and production of new products are inseparable from process technology innovation; Hatch and Mowery (1998) [5] and Hung and Norma (2018) [6] further pointed out that process innovation has more advantages than product innovation, because it is difficult to be observed and imitated by competitors. In, due to the different internal mechanisms between process innovation and product innovation, relevant research results of product innovation cannot be directly applied to process innovation [7] [8]. Therefore, research on the theme of process innovation has important theoretical significance.

The company's innovation production is mainly carried out in two ways: one is the internal research and development of the enterprise, that is, the process of "creative destruction", which is achieved by "recombining" the production factors and production conditions inside the enterprise [9]. The second is that enterprises make full use of their external resource elements for innovative production, such as seeking government R\&D support, interacting with universities and research institutions, etc. [10] [11]. Compared with internal R\&D, external channels can not only effectively compensate for the shortage of innovation resources, reduce the risk of technological innovation, but also help companies to understand and grasp external information in a timely manner and maintain the cutting-edge advancement of innovation results. Especially, in the situation of increasing shortage of innovation resources and increasingly fierce market competition, opening up innovative processes and gaining insights from people and institutions outside the company has become the consensus. Actively seeks and utilizes external Resource elements have also become an important strategic way for enterprises to enhance their technological innovation capabilities. However, due to the confidentiality of process technology and process management, enterprises are more inclined to adopt "closed door" to improve processes and technologies or to purchase and update production equipment for process innovation. According to Parida et al. (2017) [12], this greatly limits the depth and breadth of the company's technological innovation.

Through combing the process innovation literature, we find that the current research on process innovation mainly focuses on the following aspects: First, focus on the motivation of process innovation, such as Yang Zhuo et al. (2016) [13], Murat and Baki (2011) [14], Tian Hongna (2012) [15] research on factors affecting process innovation from product innovation, organizational collaboration, and environmental protection; second, focus on the effects of implementing process innovations, such as cost savings, improved product delivery speed, and improved ecological performance [16]; Third, focus on individual case studies, summarizing the experience and lessons of process innovation around the specific process innovation path and practice of the enterprise, such as Li Xianjun et al. (2016) [17], Mo Yanjun (2014) [18] and other research. Through literature review and analysis, we find that the existing research is limited to the 
process innovation from the perspective of internal independent innovation, and even treats process innovation as an auxiliary process of product innovation, and lacks the perspective of obtaining from external resources. Krishnan and Jha, (2011) also emphasize that process innovation and innovation play an important role in connecting internal and external resources to produce superior results.

Based on this, this study will focus on the external approaches to enterprise technology innovation. Based on systematically examining the actual process of enterprise process innovation, we focus on three types of external approaches: government support, industry-university-research cooperation, and customer knowledge management. Among them, the government's support for enterprise technology innovation is reflected in government policies, funds, plans and other measures to make up for the lack of innovation elements. The industry-university-research knowledge integration refers to the interaction with innovative institutions such as universities and research institutions. Customer knowledge integration is the degree to which an enterprise acquires and integrates knowledge from its customers. This study attempts to clarify the mechanism of government support, industry-university-research knowledge integration, and customer knowledge management on enterprise process innovation, and through empirical research, analyze these impact, so as to provide reference for Chinese enterprises to better use external channels to organize innovative production, and thus promote the smooth construction of innovative countries.

The structure of the article is as follows: The next section proposes the research hypothesis of the conceptual model based on the relevant theoretical basis and influencing mechanism. The third section introduces the research design of this study, including sample selection, data collection, and measurement of variables. The fourth section reports the reliability and validity analysis results of the questionnaire data, and uses the structural equations for path analysis and testing. In the final part, we discuss and analyze the results of empirical research, and propose the limitations of the article and future research directions.

\section{Theoretical Background and Research Hypothesis}

\subsection{Government Support and Process Innovation, Corporate Performance}

Firstly, based on the perspective of institutional theory, corporate strategies are driven by heterogeneous resources owned by firms [19], and are also influenced by formal and informal institutions [20] [21]. The institutional framework defines the scope and manner for enterprises to acquire resources. One is that the government plays a key role in resource allocation. The government supports have an impact on corporate sustainability and technological innovation through financial subsidies, policy loans, tax incentives, legal and regulatory services, intellectual property protection, industry technology research and development public platform construction, industry technical standards services, industry public information services, and training services [22]. In turn, Enterprises that 
have obtained government support are also equivalent to obtaining the invisible trust of the government, and the corporate reputation can be further enhanced, which inevitably promotes the value-added for enterprises. Furthermore, enterprises are more likely to acquire, agglomerate and integrate innovative resources, so that they can promote the implementation of innovation strategies, and improve technological innovation capabilities. Secondly, government policies and plans determine the direction of corporate strategy development and implementation [23], which has a significant impact on the company's ongoing operations and long-term profitability. Based on China's national conditions, the historical track of economic system reform shows that although the power of the market economy is becoming more prominent, the Chinese government's decisionmaking power in formulating policies, allocating resources, and approving projects cannot be ignored [24], and we must pay attention to the Chinese economy and should pay attention to the close interaction between government and enterprises in China's economic transformation [25] [26].

To develop quality and speed of the economy, process innovation is a key link. The government has an important influence on the direction, speed and scale of technological innovation [27]. Through specific policies and programs, the government provides additional resources to companies that meet government expectations, strengthens the willingness to foster technological innovation and optimizes innovation behavior [28]. In addition, from the perspective of innovative features, process innovation is also characterized by high risks and high investment due to various inputs such as equipment, technology, raw materials, environment, and talents [29]. Government support effectively ease the pressure on corporate resources, improve stability, and reduce innovation risks [30]. Moreover, government support can directly increase the non-operating income of enterprises by reducing tax burden or increasing financial subsidies, so that enterprises have more financial strength to invest in business and innovation activities. Based on this, we assume that:

H1: Government support positively affects process innovation.

H2: Government support positively affects corporate performance

\subsection{Industry-University-Research Knowledge Integration, Process Innovation and Enterprise Performance}

Many articles examining the relationship between innovation and knowledge show that knowledge is a pioneer in innovation [31] [32] [33]. The combination and creation of new knowledge is the key to innovation [34], and a higher level of knowledge will generate more innovation [35]. Process innovation is more inclined to internal orientation, characterized by gradual, systematic and tacit, however, by enterprises' own strength, the ability in basic process technology, machinery and equipment is still limited [36]. It means that process innovation often requires cross-functional expertise. Universities and scientific research institutions can provide enterprises with a wide range of upstream knowledge of 
knowledge chain. Through industry-university-research cooperation, enterprises can make up for their shortcomings and insufficient resources in innovation, and integrate the professional knowledge of members with different backgrounds [37]. The integration of industry, university and research knowledge also provides an alternative knowledge of process innovation issues and solutions, helping to achieve better solutions in high levels uncertainty and ambiguity condition, and reducing the uncertainty of process innovation. In addition, industry-university-research cooperation can help companies to reflect on how they implement the process, and re-analyze the entire process from start to finish to seek to improve efficiency and improve product quality, which can ensure the company's continued profitability and long-term development of. Based on this, we assume that:

H3: Industry-university-research knowledge integration significantly positively affects process innovation.

H4: Industry-university-research knowledge integration significantly affects corporate performance.

\subsection{Customer Knowledge Integration Process Innovation and Enterprise Performance}

In the past few decades, the position of customers in innovation has been successfully transformed from passive recipients to active co-designers. Ernst (2002) [38] emphasizes that customer participation in the innovation process plays an important role in reducing uncertainty. Yang (2014) [39] also believes that customer knowledge creates social capital between customers and innovative developers. Integrating customer knowledge means that the company allows customers and their needs to be introduced into the innovation process [40], that is to say, innovative developers such as R\&D teams apply customer knowledge including customer experience, perception, demand, expectations and preferences in conducting innovative activities [41]. Customer knowledge integration helps ensure ultimate customer acceptance and market adaptability. Customer knowledge integration is not uncommon in product innovation [42] [43] [44] [45]. It also plays an important role in process innovation. The ultimate goal of process innovation is to enable companies to achieve cost-effective product delivery [46] [47]. Companies that leverage customer knowledge are more likely to understand the different behaviors of their customers and gain insight into the underlying needs behind customer behavior. Combining customer knowledge helps companies improve their production processes for their target customers, improve the quality of deliverables, and shorten lead times. Kurkkio et al. (2011) [48] also pointed out that process innovation is not just a solution to the responsiveness of daily production, but a forwardlooking vision to meet future challenges, and thus requires companies to gain knowledge and feedback from interactions with customers. Companies that engage in customer knowledge integration are more motivated and willing to maintain long-term relationships with their customers in order to seek the re- 
turn on their investment in process innovation. Customers benefit from process improvement and quality reduction and cost reduction, which in turn will also strengthen cooperation with companies. As interaction and communication of information and knowledge between enterprises and customers continue to deepen, the relationship of interests and satisfaction of cooperation will also be continuously improved. Ultimately, it will have an important impact on the growth of corporate performance. In general, the above supports the following assumptions:

H5: Customer knowledge integration significantly positively affects process innovation.

H6: Customer knowledge integration significantly positively affects business performance.

\subsection{Process Innovation and Financial Performance}

Process innovation focuses on "how work is done" in an organization. Therefore, an important goal of process innovation is to improve operational efficiency and quality. Process innovation plays a positive role in the efficiency and quality of production processes by reducing costs, increasing production, improving product quality and stability, increasing market responsiveness, and promoting environmentally friendly and green production processes [49] [50]. Especially in mature markets that products tend to be homogeneous, to achieve higher market share and economic benefits, companies that focus on process innovation are more likely to have a competitive cost structure to manufacture and deliver products faster, more flexibly, and cheaper (Congden and Schroeder, 1996) [51]. In addition, process innovation is often hidden within the organization, and this concealment makes it difficult for competitors to understand and imitate [52], so the time and space for companies to add value first is maintained. Therefore, as a scarce, valuable, and difficult to imitate resource (Barney, 1991), process innovation is considered to be a major source for creating sustainable competitive advantage and improving organizational performance [52]. Based on this, we assume that:

H7: Process innovation actively promotes corporate performance.

\subsection{Government Support and Industry-University-Research Knowledge Integration}

The theory of national innovation system believes that there is a wide interaction between universities and industry, and the government plays a direct or indirect intervention role in this interaction. The practical experience of innovation development at home and abroad also shows that government support is an important force to promote the innovation and development of industry, academia and research [53] [54]. On the one hand, combined with the research of Arrow (1962) [55] and Tassey (2004) [56], the cooperation between industry, university and research is still essentially a knowledge production activity. The spillover characteristics of knowledge production make the industry-university-research 
cooperation entities unable to enjoy the full benefits of the innovation results. Without external intervention, the actual results of the industry-university-research cooperation will be lower than the social optimal level, causing "market failure". Government support can build an industry-university-research innovation platform, formulate relevant legal norms, strengthen intervention and supervision of industry-university-research innovations, constrain the behavior of various subjects, and reduce the "free-riding" phenomenon in the process of industry-university-research cooperation, thereby reducing the spillover of innovation results [57]. On the other hand, as a kind of knowledge production process, industry-university-research knowledge integration requires a large amount of capital investment. If only relying on the cooperation of various entities to raise funds, it will be difficult to meet the needs of the innovation process. The government's financial support for the innovation, can not only directly increase the scale of funds, but also attract more investment from industry-university-research entities, as well as related external funds, thus alleviating the tight capital situation in the process of industry-university-research cooperation [58]. Furthermore, introducing government supervision and support in the industry-university-research innovation platform, can establish a corresponding interest coordination and distribution mechanism, which helps to reduce the transaction costs of innovation entities and the risk of collaborative innovation failure. As a Whole, we assume that:

H8: Government support significantly positively affects industry-university-research knowledge integration.

\section{Method}

\subsection{Data Collection}

Our research is based on the high-tech enterprises in China's manufacturing industry. High-tech enterprises have typical characteristics of technology-intensive and knowledge-intensive. They have strong sense of innovation, and have more active innovation activities, which is suitable as a sample to the research of enterprise process innovation. The samples come from China's Pearl River Delta, Yangtze River Delta, and Bohai Economic Zone. They cover equipment manufacturing enterprises in eight industries, including biology and pharmaceuticals, computer and telecommunication equipment, chemicals, medical equipment, electronic and electrical equipment, industrial machinery, transportation equipment, and new materials. After randomly selecting 5597 companies through the Yellow Pages of the Enterprise, we further removed the missing information and non-compliant enterprises, and 3218 companies remained. During the period from August to December in 2012, we collected 100 valid questionnaires through interviews and on-site interviews, and collected 200 valid questionnaires by means of mail questionnaires. We collected 300 questionnaires in total with a recovery rate of $12.61 \%$. Since this study needs to explore the impact of industry-university-research knowledge integration on process innovation, we further 
screened the samples and eliminated the enterprises that did not have the industry-university-research cooperation. The final available samples were 262.The sample distribution characteristics of the recovered samples are shown in Table 1 .

\subsection{Measurement}

In order to fully guarantee the reliability and validity of the measurement tools, we use the mature scale design questionnaire in the existing literature, and based on this, adjust the appropriateness according to the research objectives and content. This study used the Likert seven-level scale to measure the relationship between government support, industry-university-research knowledge integration, customer knowledge integration, process innovation, and firm performance. In addition, according to the existing research, this paper analyzes the production control variables of the enterprise scale, the industry where the enterprise is located, and the enterprise.

In order to fully guarantee the reliability and validity of the measurement tools,

Table 1. Profile of sample firms.

\begin{tabular}{|c|c|c|}
\hline Statistic content Sample size & & Percentage (\%) \\
\hline \multicolumn{3}{|l|}{ Industry } \\
\hline Biology and pharmaceuticals & 18 & 6.9 \\
\hline Computer and telecommunication equipment & 25 & 9.5 \\
\hline Chemicals & 48 & 18.3 \\
\hline Medical equipment & 25 & 9.5 \\
\hline Electronics and electrical equipment & 43 & 16.4 \\
\hline Industrial machinery & 44 & 16.8 \\
\hline Transportation equipment & 34 & 13 \\
\hline New materials & 25 & 9.5 \\
\hline \multicolumn{3}{|l|}{ Ownership } \\
\hline State-owned & 89 & 34 \\
\hline Privately owned & 94 & 35.9 \\
\hline Joint venture & 41 & 15.6 \\
\hline Foreign investment & 38 & 14.5 \\
\hline \multicolumn{3}{|l|}{ Employees' number } \\
\hline 101 to 200 & 56 & 21.4 \\
\hline 201 to 300 & 53 & 20.2 \\
\hline 30 to 500 & 60 & 22.9 \\
\hline 501 to 1000 & 43 & 16.4 \\
\hline 1000 or more & 50 & 19.1 \\
\hline Total & 262 & 100 \\
\hline
\end{tabular}


we use the mature Likert seven-level scale design questionnaire in the existing literature, and based on this, adjust the appropriateness according to the research objectives and content. Government supported measurement uses the scale design from Li and Atuahene-Gima (2001), focusing on the benefits of policies and plans, as well as technical support, financial support, and commercial licenses that companies receive from governments and related agencies. The measurement of industry-university-research knowledge integration focuses on the degree of acquiring and utilizing of knowledge from universities and research institutions, using the scale of Yli-Renko et al. (2001). Similarly, the four measurement items of customer knowledge integration measure the extent to which a company acquires and utilizes customer knowledge. The measurement of process innovation is adapted from the scales of Tellis, Prabhu \& Chandy (2009) to measure the company's leading position in new process development and application. In addition, according to the existing research, we use the enterprise scale, the industry, and the enterprise ownership and the R\&D investment as the control variables of process innovation.

\section{Analysis and Results}

\subsection{Measurement Model}

First, a reliability test is performed. We used Cronbach's $\alpha$ coefficient to measure internal consistency. According to Table 2, Cronbach's $\alpha$ values ranged from 0.833 to 0.884 , both above the critical value of 0.70 [59]. At the same time, we can see that the value of the combined reliability is also higher than the critical value of 0.70 . Based on this, we believe that the internal reliability of this study is good enough to pass internal consistency test.

Validity tests for this study included content validity, convergence validity, and discriminant validity, and results are illustrated in the Table 3. For the content validity, on the basis of literature review in this research field, we invite research experts and supply chain management personnel in the field to discuss, evaluate and adjust the scales which has been used by domestic and foreign scholars. It can be considered that the content validity of the scale is well guaranteed. In terms of convergence validity and discriminant validity, we use confirmatory factor analysis (CFA) to test. The results run by AMOS software shows that our model offers a good fit to the sample data: $\chi^{2}=270.909, \chi^{2} / \mathrm{df}=1.513$, FI $=0.909>0.900, \mathrm{NFI}=0.913, \mathrm{IFI}=0.969, \mathrm{TLI}=0.963, \mathrm{CFI}=0.968, \mathrm{RMSEA}=$ 0.046 . In the test of convergence validity, most of the standard loadings are greater than 0.7 , and only a few measurement items' standard loading are between 0.6 and 0.7. At the same time, the AVE value of the five variables is between 0.560 and 0.652 . The above results indicate that the scale has acceptable convergence validity. In the test of discriminant validity, as shown in the Table 3 , the AVE square root of each variable is greater than the correlation coefficient of the variable with other variables [60] [62], and results explains that variables have better Distinguish validity. 
Table 2. Factor loadings of scale items (CFA factor analysis).

Government support (Cronbach's $\alpha=0.846$, C.R. $=0.853, \mathrm{AVE}=0.593$ )

1) Implemented policies and programs that have been beneficial to your company's operations.

2) Provided needed technology information and technical support to your company.

3) Played a significant role in providing financial support for your company.

4) Helped your company to obtain licenses for imports of technology, manufacturing and other equipment.

Universities and research institute's knowledge integration (Cronbach's $\alpha=0.884$, C.R. $=0.890$, AVE $=0.621$ )

1) We are able to obtain a tremendous amount of our technological knowledge from universities/research institutes.

2) We rapidly respond to technological changes in our industry by applying what we know from universities/research institutes.

3) University/research institute's technological knowledge has enriched the basic understanding of our innovation activities.

4) University/research institute's technological knowledge has reduced the uncertainty of our innovation activities.

5) University/research institute's technological knowledge helps us to identify new aspects of innovation activities that would otherwise go unnoticed.

Customer's knowledge integration (Cronbach's $\alpha=0.833, \mathrm{C} . \mathrm{R} .=0.847, \mathrm{AVE}=0.589$ )

1) We are able to obtain a tremendous amount of our product knowledge from customers.

2) We rapidly respond to technological changes in our industry by applying what we know from customers.

3) Customers' technological knowledge has reduced the uncertainty of our innovation activities.

Process innovation (Cronbach's $\alpha=0.845$, C.R. $=0.854, \mathrm{AVE}=0.560$ )

1) We are learning more about the newest processes than our competitors.

2) We are the first within the industry to deploy new processes.

3) We keep up with the latest process developments.

4) We frequently introduce processes that are radically different from existing processes in the industry.

Table 3. Descriptive statistics and pearson correlation matrix.

\begin{tabular}{ccccccccccc}
\hline Variables & Mean & S.D. & 1 & 2 & 3 & 4 & 5 \\
\hline 1) Government support & 4.587 & 1.127 & $(0.770)$ & & & & & \\
2) Customer's Knowledge integration & 4.015 & 1.225 & -0.017 & $(0.767)$ & & & & \\
3) Universities and research institute's knowledge integration & 5.134 & 1.145 & $0.258^{* *}$ & 0.049 & $(0.788)$ & & \\
4) Process innovation & 5.116 & 1.024 & $0.434^{* *}$ & -0.097 & $0.245^{* *}$ & $(0.773)$ & \\
5) Company performance & 4.768 & 1.047 & $0.445^{* *}$ & -0.020 & $0.153^{*}$ & $0.408^{* *}$ & $(0.807)$ \\
\hline
\end{tabular}

Notes: Numbers in brackets on the diagonal of matrix are the square root of AVE; ${ }^{* *} \mathrm{p}<0.01 ;{ }^{*} \mathrm{p}<0.05$. 


\subsection{Hypothesis Testing and Results}

The theoretical model was tested by using AMOS software. The results show that the structural equation model fits well with the actual data: $\chi^{2}=356.941, \chi^{2} / \mathrm{df}=$ 1.552 , GFI $=0.916>0.900, \mathrm{NFI}=0.92>0.900, \mathrm{IFI}=0.958,>0.900 \mathrm{TLI}=$ $0.948>0.900$, CFI $=0.957>0.900$, RMSEA $=0.046$. The results of the path analysis are shown in Figure 1. Government support has a significant impact on process innovation $(b=0.414, \mathrm{p}<0.001)$, firm performance $(\mathrm{b}=0.389, \mathrm{p}<$ $0.001)$, and industry-university-research knowledge integration $(\mathrm{b}=0.309, \mathrm{p}<$ 0.001), so H1, H2, H8 can be supported. The industry-university-research knowledge integration significantly positively affects process innovation $(b=$ $\left.0.155^{\star}, \mathrm{p}<0.05\right)$, but not significant influences firm performance $(\mathrm{b}=0.067, \mathrm{p}>$ 0.05), thus $\mathrm{H} 3$ is supported and $\mathrm{H} 4$ is rejected. Customer knowledge integration has a significant negative impact on process innovation $(b=-0.150, p<0.05)$, but the impact on firm performance $(b=0.003, p>0.05)$ was not significant, so both $\mathrm{H} 5$ and $\mathrm{H} 6$ are not supported. Process innovation significantly positively affect firm performance $(b=0.250, p<0.01)$ and it supports $\mathrm{H} 7$ (Figure 1).

\section{Conclusions and Discussion}

\subsection{Research Conclusions and Theoretical Contributions}

Based on the empirical samples of high-tech manufacturing in China's Bohai Rim, Yangtze River Delta and Pearl River Delta regions, this paper explores the impact mechanism of external resource acquisition on process innovation and draws the following conclusions:

1) Previous researches have focused on overall innovation performance [61] [62], product innovation [63] [64], incremental innovation and radical innovation (Arnold et al., 72011; Zhou and Li, 2012) [65] [66] to explore the role of government, customers, universities and research institutions in innovation. Based on existing research on the differences between product innovation and process innovation [67] [68], this paper proceeding from process innovation,

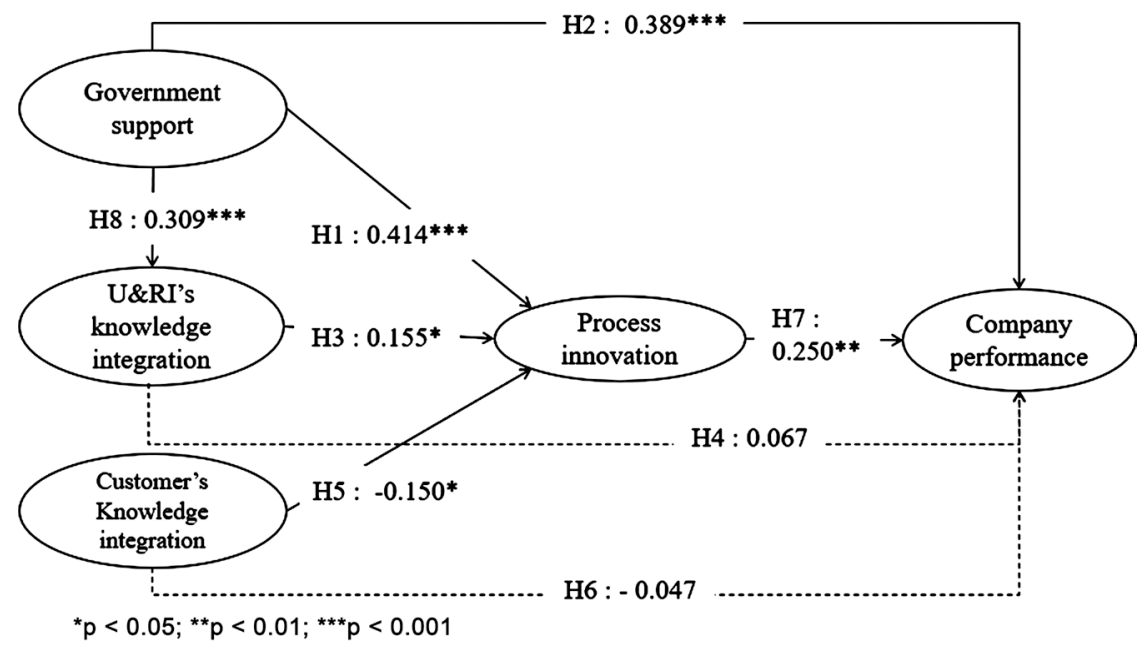

Figure 1. SEM results. 
thus it further enriches and improves the research on corporate innovation.

2) Government support has a positive influence on process innovation and improves corporate performance. These results further support Zeng et al. (2016) [69], Kang and Park (2012) [70], Li and Atuahene-Gima (2001) [30], Looy et al. (2003) [71] and other empirical conclusions on government support positively affecting enterprise innovation. At the same time, it confirms that the government and its institutions exert applicable and significant role in emerging market's economy and innovation activities represented by China. In addition, government support positively influences industry-university-research knowledge integration, and this conclusion is consistent with existing empirical evidence of the three-helix theory [72] [73] [74].

3) The industry-university-research knowledge integration significantly affects process innovation, but does not impose significantly effect on corporate performance. The industry-university-research knowledge integration can significantly influence process innovation, supporting the research by Un and Asakawa (2015) [37], Parida et al., (2017) [12]. They claim that although process innovation is an internal behavior, it can still benefit from external innovation cooperation. The positive impact of industry-university-research knowledge integration on corporate performance is not good. The possible reason is that the research results are limited by the research method we used. More specifically, the data are collected in the same time period which belongs to static research, but the impact of industry-university-research knowledge integration on corporate performance has a time lag. Therefore, industry-university-research knowledge integration does not significantly promote corporate performance within this framework.

4) Customer knowledge integration has a significant negative effect on process innovation and has no significant influence on firm performance. This conclusion is inconsistent with the hypothesis of this paper. For this, we discuss reasons by searching existing literature. First, there is a risk of customer knowledge integration in the innovation process: a) Excessive attention to customers' needs and personality may cause excessive dependence on customers [75]. b) Customer knowledge transfers from outside to internal departments of the company and from one department to another suffer from risk of loss or distortion [76] [77]. c) Innovators and customers are not necessarily willing and able to interact with knowledge integration [78], so customer knowledge integration may have a certain negative effect on process innovation. However, it is not wise to advocate that customer knowledge integration should not be carried out in the process innovation. Enkel et al. (2005) [79] pointed out empirically that compared with the integration of customer knowledge, the risk of not having customer knowledge is greater because it means that the company's products will not be market-oriented, and not using customer knowledge will limit innovation. Second, Lee and Kim (2010) [80], Anne and Salminen (2010) [81], and Reimann et al. (2010) [82] found that customer knowledge plays an important role in reducing 
corporate costs, rather than overall corporate performance. More generally, companies in mature markets tend to use customer knowledge to improve production processes and improve business efficiency, rather than gaining operational profitability and increasing market share (Hung and Norma, 2018). In other words, the impact of customer knowledge on business performance is not straightforward.

\subsection{Managerial Implications}

This study explores the impact of external resource acquisition on innovation from the perspective of process innovation, and it provided certain work suggestions for the management practice of high-tech manufacturing. To implement innovation, enterprises must not only initiate product innovation, but also work on process innovation. The ambiguity and ambiguity of process innovation make it impossible to be easily imitated by competitors, thus providing companies with a hidden competitive advantage (Hung and Norma, 2018; Hatch and Mowery, 1998). Companies must focus on process innovation's depth (connecting system knowledge, tools, and processes), as well as process innovation's width (seeking new ways to reconfigure system knowledge, tools, and processes) (Parida et al., 2017), so that companies can make and deliver products to consumers faster, cheaper and more flexibly and create a unique competitive advantage.

While enterprises are exerting their strength in process innovation, they must also pay attention to the acquisition and utilization of external resources. It is not appropriate to carry out process innovation in isolation. Compared with product innovation, the characteristics of process innovation make most companies tend to "closed doors" for process improvement. However, in the era of open cooperation and innovation, enterprises should attach importance to cooperation and interaction with relevant upstream, downstream and other related partners in process innovation, promoting the effective flow of new technologies, new knowledge, new information and other resources, and promoting the identification, absorption, digestion and application of external resources. Thereby, it will enhance companies' resource endowment and knowledge accumulation in process innovation.

Finally, when enterprises use external resources for process innovation, they need to combine the actual situation of the enterprise, such as the scale and the strategic decision of the enterprise and the external market environment. Besides, the influence of the acquisition and application with different external resources on innovation performance and economic benefits of the enterprise are different in the long-term and short-term. And companies enterprises should avoid excessive dependence on some external resources.

\subsection{Limitations and Future Research Directions}

Although this research has achieved certain research results, there are some li- 
mitations in the which are embodied in: 1) The limitations of the research sample. The samples of this study are mainly from Bohai Rim, Yangtze River Delta and Pearl River Delta regions', where the innovation activities in China are active. Future research can further expand the scope of research. 2) Limitations of measurement methods. The measurement of firm performance in this study is carried out in the form of Likert scale. It means that the subjective consciousness of the interviewed managers may influence results. Subsequent research can use objective data to measure firm performance and other variables. 3) Limitations of the research object, this study mainly analyzes the role of government, customers, universities and research institutions on process innovation. Future research can also conduct research on supplier competitors and intermediary service organizations. In addition, companies' access to resources from governments, customers, universities, and research institutions are more general to the framework of this research. Scholars believe that government power may also force by subsidies, loans, professional services, etc. [83] [84], and the role of customers can also influence the process innovation by means of customer participation, customer interaction, and co-creation [85]. In addition, the role of universities and research institutions may also be different. It may therefore require different treatment [86] [87].

\section{Conflicts of Interest}

The authors declare no conflicts of interest regarding the publication of this paper.

\section{References}

[1] Utterback, J.M. and Abernathy, W.J. (1975) A Dynamic Model of Process and Product Innovation. Omega, 3, 639-656. https://doi.org/10.1016/0305-0483(75)90068-7

[2] Miozzo, M. and Dewick, P. (2002) Building Competitive Advantage: Innovation and Corporate Governance in European Construction. Research Policy, 31, 989-1008. https://doi.org/10.1016/S0048-7333(01)00173-1

[3] Frishammar, J., Kurkkio, M., Abrahamsson, L. and Lichtenthaler, U. (2012) Antecedents and Consequences of Firms' Process Innovation Capability: A Literature Review and a Conceptual Framework. IEEE Transactions on Engineering Management, 59, 519-529. https://doi.org/10.1109/TEM.2012.2187660

[4] Lim, L.P.L., Garnsey, E. and Gregory, M. (2010) Product and Process Innovation in Biopharmaceuticals: A New Perspective on Development. $R \& D$ Management, 36, 27-36. https://doi.org/10.1111/j.1467-9310.2006.00413.x

[5] Hung, N. and Norma, H. (2018) Leveraging Customer Knowledge to Enhance Process Innovation. Business Process Management Journal, 25, 307-322.

[6] Hatch, N.W. and Mowery, D.C. (1998) Process Innovation and Learning by Doing in Semiconductor Manufacturing. Management Science, 44, 1461-1593. https://doi.org/10.1287/mnsc.44.11.1461

[7] Damanpour, F. and Gopalakrishnan, S. (2001) The Dynamics of the Adoption of Product and Process Innovations in Organizations. Journal of Management Studies, 
38, 45-65. https://doi.org/10.1111/1467-6486.00227

[8] Damanpour, F. (2010) An Integration of Research Findings of Effects of Firm Size and Market Competition on Product and Process Innovations. British Journal of Management, 21, 996-1010. https://doi.org/10.1111/j.1467-8551.2009.00628.x

[9] Schumpeter, J.A. (1912) Theory of Economic Development. Routledge, London.

[10] Rui, B. (1999) The Diffusion of Process Innovations: A Selective Review. International Journal of the Economics of Business, 6, 107-129. https://doi.org/10.1080/13571519984359

[11] Pilav-Velić, A. and Marjanovic, O. (2016) Integrating Open Innovation and Business Process Innovation: Insights from a Large-Scale Study on a Transition Economy. Information and Management, 53, 398-408. https://doi.org/10.1016/j.im.2015.12.004

[12] Parida, V., Patel, P.C., Frishammar, J. and Wincent, J. (2017) Managing the Front-End Phase of Process Innovation under Conditions of High Uncertainty. Quality and Quantity. International Journal of Methodology, 51, 1983-2000. https://doi.org/10.1007/s11135-016-0376-4

[13] Yang, Z. (2016) Research on the Co-Operation Mechanism of Product Innovation, Process Innovation and Business Model Innovation of Science and Technology Enterprises. Proceedings of the 12 th China Science and Technology Policy and Management Academic Conference, China Science and Technology Policy Research Association, 15.

[14] Murat Ar, I. and Baki, B. (2011) Antecedents and Performance Impacts of Product versus Process Innovation: Empirical Evidence from SMEs Located in Turkish Science and Technology Parks. European Journal of Innovation Management, 14, 172-206. https://doi.org/10.1108/14601061111124885

[15] Tian, H. (2012) Research on Green Process Innovation Model of Manufacturing Industry Based on Power Source. Learning and Exploration, No.8, 116-118.

[16] Chen, Y.S., Lai, S.B. and Wen, C.T. (2006) The Influence of Green Innovation Performance on Corporate Advantage in Taiwan. Journal of Business Ethics, 67, 331-339. https://doi.org/10.1007/s10551-006-9025-5

[17] Li, X.J., Gao, G., Meng, D.H. and Zhang, B. (2016) Research on Process Innovation Mechanism: Empirical Study from Chinese Automobile Enterprises. Research Management, 37, 37-45.

[18] Mo, Y.J. (2014) Discussion on Process Innovation of State-Owned Resource-Based Enterprises. New Economy, No.23, 88-89.

[19] Barney, J. (1991) Firm Resources and Sustained Competitive Advantage. Journal of Management, 17, 99-120. https://doi.org/10.1177/014920639101700108

[20] Oliver, C. (1997) Sustainable Competitive Advantage: Combining Institutional and Resource-Based Views. Strategic Management Journal, 18, 697-713. https://doi.org/10.1002/(SICI)1097-0266(199710)18:9<697::AID-SMJ909>3.0.CO;2-C

[21] Scott, W.R. (1995) Institutions and Organizations: Ideas and Interests. Sage Publications, Los Angeles, CA.

[22] Yang, X.Y., Liu, B., Chen, K.H., et al. (2015) The Impact of Government Support on KIBS Enterprise Innovation Activity. Science of Science and Management of Science \& Technology, 36, 13-23.

[23] Ingram, P. and Silverman, B.S. (2002) Introduction: The New Institutionalism in Strategic Management. Advances in Strategic Management, 19, 1-30.

https://doi.org/10.1016/S0742-3322(02)19001-2 
[24] Peng, M.W. and Luo, Y. (2000) Managerial Ties and Firm Performance in a Transition Economy: The Nature of a Micro-Macro Link. Academy of Management Journal, 43, 486-501.

[25] Guo, H., Xu, E. and Jacobs, M. (2014) Managerial Political Ties and Firm Performance during Institutional Transitions: An Analysis of Mediating Mechanisms. Journal of Business Research, 67, 116-127. https://doi.org/10.1016/j.jbusres.2012.11.009

[26] Tjosvold, D., Peng, A.C., Chen, Y.F. and Fang, S. (2008) Business and Government Interdependence in China: Cooperative Goals to Develop Industries and the Marketplace. Asia Pacific Journal of Management, 25, 225-249. https://doi.org/10.1007/s10490-007-9063-2

[27] Lichtenberg, F.R. (1988) Government Subsidies to Private Military R \& D Investment: DOD's IR \& D Policy. Defense Economics, 1, 49-158.

[28] Hong, Y. and Li, Y.M. (2012) Research on Policy Transmission Mechanism of Independent Innovation. Studies in Science of Science, 30, 449-457.

[29] Gao, H.W. (2011) Research on the Extrusion Effect of Government Subsidy on the R \& D of Large State-Owned Enterprises. China Science and Technology Forum, No.8, 15-20.

[30] Li, H. and Atuahene-Gima, K. (2001) Product Innovation Strategy and the Performance of New Technology Ventures in China. Academy of Management Journal, 44, 1123-1134.

[31] Cohen, W.M. and Levinthal, D.A. (1990) Absorptive Capacity: A New Perspective on Learning and Innovation. Administrative Science Quarterly, 35, 128-152. https://doi.org/10.2307/2393553

[32] Tsai, W. (2001) Knowledge Transfer in Intraorganizational Networks: Effects of Network Position and Absorptive Capacity on Business Unit Innovation and Performance. Academy of Management Journal, 44, 996-1004.

[33] Camisón, C. and Forés, B. (2010) Knowledge Absorptive Capacity: New Insights for Its Conceptualization and Measurement. Journal of Business Research, 63, 707-715. https://doi.org/10.1016/j.jbusres.2009.04.022

[34] Kogut, B. and Zander, U. (1992) Knowledge of the Firm, Combinative Capabilities, and the Replication of Technology. Organization Science, 3, 383-397.

https://doi.org/10.1287/orsc.3.3.383

[35] Collins, C.J. and Smith, K.G. (2006) Knowledge Exchange and Combination: The Role of Human Resource Practices in the Performance of High-Technology Firms. Academy of Management Journal, 49, 544-560. https://doi.org/10.5465/amj.2006.21794671

[36] Robertson, P.L., Casali, G.L. and Jacobson, D. (2012) Managing Open Incremental Process Innovation: Absorptive Capacity and Distributed Learning. Research Policy, 41, 822-832. https://doi.org/10.1016/j.respol.2012.02.008

[37] Un, C.A. and Asakawa, K. (2015) Types of R \& D Collaborations and Process Innovation: The Benefit of Collaborating Upstream in the Knowledge Chain. Journal of Product Innovation Management, 32, 138-153. https://doi.org/10.1111/jpim.12229

[38] Ernst, H. (2002) Success Factors of New Product Development: A Review of the Empirical Literature. International Journal of Management Reviews, 4, 1-40. https://doi.org/10.1111/1468-2370.00075

[39] Yang, Z. and Peterson, R.T. (2004) Customer Perceived Value, Satisfaction, and Loyalty: The Role of Switching Costs. Psychology and Marketing, 21, 799-822. 
https://doi.org/10.1002/mar.20030

[40] Iansiti, M. and Clark, K.B. (1994) Integration and Dynamic Capability: Evidence from Product Development in Automobiles and Mainframe Computers. Industrial and Corporate Change, 3, 557-605. https://doi.org/10.1093/icc/3.3.557

[41] Rosell, D. T., Lakemond, N. and Nazli Wasti, S. (2014) Integrating Knowledge with Suppliers at the R \& D-Manufacturing Interface. Journal of Manufacturing Technology Management, 25, 240-257. https://doi.org/10.1108/JMTM-12-2013-0171

[42] Lau, A.K.W., Tang, E. and Yam, R.C.M. (2010) Effects of Supplier and Customer Integration on Product Innovation and Performance: Empirical Evidence in Hong Kong Manufacturers. Journal of Product Innovation Management, 27, 761-777. https://doi.org/10.1111/j.1540-5885.2010.00749.x

[43] Moon, H., Miller, D.R. and Kim, S.H. (2013) Product Design Innovation and Customer Value: Cross-Cultural Research in the United States and Korea. Journal of Product Innovation Management, 30, 31-43. https://doi.org/10.1111/j.1540-5885.2012.00984.x

[44] Yao, S. and Wang, Y. (2011) The Influence Mechanism of Customer Participation in New Product Development on Enterprise Technology Innovation Performance-Based on Empirical Research in BB Situation. Science of Science and Management of Science \& Technology, 32, 34-41.

[45] Wang, L., Fang, W. and Luo, W. (2011) Research on the Relationship among Customer Knowledge, Creativity and Innovation Behavior. Studies in Science of Science, 29.

[46] Faems, D., Van Looy, B. and Debackere, K. (2005) Interorganizational Collaboration and Innovation: Toward a Portfolio Approach. Journal of Product Innovation Management, 22, 238-250. https://doi.org/10.1111/j.0737-6782.2005.00120.x

[47] Kim, B. (2000) Coordinating an Innovation in Supply Chain Management. European Journal of Operational Research, 123, 568-584. https://doi.org/10.1016/S0377-2217(99)00113-7

[48] Kurkkio, M., Frishammar, J. and Lichtenthaler, U. (2011) Where Process Development Begins: A Multiple Case Study of Front End Activities in Process Firms. Technovation, 31, 490-504. https://doi.org/10.1016/j.technovation.2011.05.004

[49] Pisano, G.P. (1997) The Development Factory: Unlocking the Potential of Process Innovation. Harvard Business Press, Boston, MA.

[50] Lager, T. (2002) A Structural Analysis of Process Development in Process Industry: A New Classification System for Strategic Project Selection and Portfolio Balancing. $R \& D$ Management, 32, 87-95. https://doi.org/10.1111/1467-9310.00241

[51] Congden, S.W. and Schroeder, D.M. (1996) Competitive Strategy and the Adoption and Usage of Process Innovation. International Journal of Commerce and Management, 6, 5-21.

[52] Al-Sa'di, A.F., Abdallah, A.B. and Dahiyat, S.E. (2017) The Mediating Role of Product and Process Innovations on the Relationship between Knowledge Management and Operational Performance in Manufacturing Companies in Jordan. Business Process Management Journal, 23, 349-376. https://doi.org/10.1108/BPMJ-03-2016-0047

[53] Hong, Y.X. (2014) Economic Analysis of Collaborative Innovation in Industry. Economic Science, 36, 56-64.

[54] Bai, J.H. and Zhai, Y.C. (2015) Does Government Support Promote Collaborative Innovation in Industry. Statistical Research, 32, 43-50. 
[55] Arrow, K.J. (1962) Economic Welfare and the Allocation of Resources for Invention. In: Rowley, C.K., Ed., Readings in Industrial Economics, Palgrave Macmillan, London, 219-236.

[56] Tassey, G. (2004) Policy Issues for R \& D Investment in a Knowledge-Based Economy. The Journal of Technology Transfer, 29, 153-185. https://doi.org/10.1023/B:JOTT.0000019536.59816.ae

[57] Kasahara, H., Shimotsu, K. and Suzuki, M. (2014) Does an R \& D Tax Credit Affect R \& D Expenditure? The Japanese R \& D Tax Credit Reform in 2003. Journal of the Japanese and International Economies, 31, 72-97.

[58] Li, X. (2012) Behind the Recent Surge of Chinese Patenting: An Institutional View. Research Policy, 41, 236-249. https://doi.org/10.1016/j.respol.2011.07.003

[59] Nunnally, J.C. and Bernstein, I.H. (1994) Psychological Theory. 3rd Edition, MacGraw-Hill, New York, 131-147.

[60] Fornell, C. and Larcker, D.F. (1981) Evaluating Structural Equation Models with Unobservable Variables and Measurement Error. Journal of Marketing Research, 18, 39-50. https://doi.org/10.1177/002224378101800104

[61] Carayannis, E.G., Alexander, J. and Ioannidis, A. (2000) Leveraging Knowledge, Learning, and Innovation in Forming Strategic Government-University-Industry (GUI) R \& D Partnerships in the US, Germany, and France. Technovation, 20, 477-488. https://doi.org/10.1016/S0166-4972(99)00162-5

[62] Marques, J.P.C., Caraça, J.M.G. and Diz, H. (2006) How Can University-IndustryGovernment Interactions Change the Innovation Scenario in Portugal?-The Case of the University of Coimbra. Technovation, 26, 534-542. https://doi.org/10.1016/j.technovation.2005.04.005

[63] Freel, M. (2000) External Linkages and Product Innovation in Small Manufacturing Firms. Entrepreneurship \& Regional Development, 12, 245-266. https://doi.org/10.1080/089856200413482

[64] Jean, R.J.B., Sinkovics, R.R. and Hiebaum, T.P. (2014) The Effects of Supplier Involvement and Knowledge Protection on Product Innovation in Customer-Supplier Relationships: A Study of Global Automotive Suppliers in China. Journal of Product Innovation Management, 31, 98-113. https://doi.org/10.1111/jpim.12082

[65] Arnold, T.J., Fang, E.E. and Palmatier, R.W. (2011) The Effects of Customer Acquisition and Retention Orientations on a Firm's Radical and Incremental Innovation Performance. Journal of the Academy of Marketing Science, 39, 234-251. https://doi.org/10.1007/s11747-010-0203-8

[66] Zhou, K.Z. and Li, C.B. (2012) How Knowledge Affects Radical Innovation: Knowledge Base, Market Knowledge Acquisition, and Internal Knowledge Sharing. Strategic Management Journal, 33, 1090-1102. https://doi.org/10.1002/smj.1959

[67] Gupta, A.K., Raj, S.P. and Wilemon, D.A. (1986) A Model for Studying R \& D and Marketing Interface in the Product Innovation Process. Journal of Marketing, 50, 7-17.

[68] Cohen, W.M. and Klepper, S. (1996) Firm Size and the Nature of Innovation within Industries: The Case of Process and Product R \& D. Review of Economics and Statistics, 78, 232-243. https://doi.org/10.2307/2109925

[69] Zeng, P., Liu, Y. and Wu, X. (2016) The Impact of Government Support on Enterprise Technology Innovation-Based on the Integration Perspective of ResourceBased View and Institutional Foundation View. Economic Management, No. 2, $14-25$.

[70] Kang, K.N. and Park, H. (2012) Influence of Government R \& D Support and In- 
ter-Firm Collaborations on Innovation in Korean Biotechnology SMEs. Technovation, 32, 68-78. https://doi.org/10.1016/j.technovation.2011.08.004

[71] Looy, B.V., Debackere, K. and Andries, P. (2003) Policies to Stimulate Regional Innovation Capabilities via University-Industry Collaboration: An Analysis and an Assessment. $R$ \& D Management, 33, 209-229.

https://doi.org/10.1111/1467-9310.00293

[72] Mansfield, E. and Lee, J.Y. (1996) The Modern University: Contributor to Industrial Innovation and Recipient of Industrial R \& D Support. Research Policy, 25, 1047-1058. https://doi.org/10.1016/S0048-7333(96)00893-1

[73] Etzkowitz, H. and Leydesdorff, L. (2000) The Dynamics of Innovation: From National Systems and "Mode 2" to a Triple Helix of University-Industry-Government Relations. Research Policy, 29, 109-123. https://doi.org/10.1016/S0048-7333(99)00055-4

[74] Zhuang, T. and Wu, H. (2013) Research on the Three-Helical Measurement of China's Government-Industry-Study Based on Patent Data-Concurrently on the Role of Government in Industry-University-Research Cooperation. Management World, No.8, 175-176.

[75] Schaarschmidt, M. and Kilian, T. (2014) Impediments to Customer Integration into the Innovation Process: A Case Study in the Telecommunications Industry. European Management Journal, 32, 350-361. https://doi.org/10.1016/j.emj.2013.04.004

[76] von Hippel, E. (1994) Sticky Information and the Locus of Problem Solving: Implications for Innovation. Management Science, 40, 429-548. https://doi.org/10.1287/mnsc.40.4.429

[77] Bosch-Sijtsema, P. and Bosch, J. (2015) User Involvement throughout the Innovation Process in High-Tech Industries. Journal of Product Innovation Management, 32, 793-807. https://doi.org/10.1111/jpim.12233

[78] Ulwick, A.W. (2002) Turn Customer Input into Innovation. Harvard Business Review, 80, 91-97.

[79] Enkel, E., Kausch, C.T. and Gassmann, O. (2005) Managing the Risk of Customer Integration. European Management Journal, 23, 203-213. https://doi.org/10.1016/j.emj.2005.02.005

[80] Lee, R.P. and Kim, D. (2010) Implications of Service Processes Outsourcing on Firm Value. Industrial Marketing Management, 39, 853-861.

[81] Jalkala, A. and Salminen, R.T. (2010) Practices and Functions of Customer Reference Marketing-Leveraging Customer References as Marketing Assets. Industrial Marketing Management, 39, 975-985.

https://doi.org/10.1016/j.indmarman.2010.06.017

[82] Reimann, M., Schilke, O. and Thomas, J.S. (2010) Customer Relationship Management and Firm Performance: The Mediating Role of Business Strategy. Journal of the Academy of Marketing Science, 38, 326-346. https://doi.org/10.1007/s11747-009-0164-y

[83] Pavitt, K. and Walker, W. (1976) Government Policies towards Industrial Innovation: A Review. Research Policy, 5, 11-97. https://doi.org/10.1016/0048-7333(76)90017-2

[84] Foss, N.J., Laursen, K. and Pedersen, T. (2011) Linking Customer Interaction and Innovation: The Mediating Role of New Organizational Practices. Organization Science, 22, 980-999. https://doi.org/10.1287/orsc.1100.0584

[85] Piller, F.T., Ihl, C. and Vossen, A. (2010) A Typology of Customer Co-Creation in the Innovation Process. SSRN Electronic Journal. 
[86] Fritsch, M. and Schwirten, C. (1999) Enterprise-University Co-Operation and the Role of Public Research Institutions in Regional Innovation Systems. Industry and Innovation, 6, 69-83. https://doi.org/10.1080/13662719900000005

[87] Robin, S. and Schubert, T. (2013) Cooperation with Public Research Institutions and Success in Innovation: Evidence from France and Germany. Research Policy, 42, 149-166. https://doi.org/10.1016/j.respol.2012.06.002 